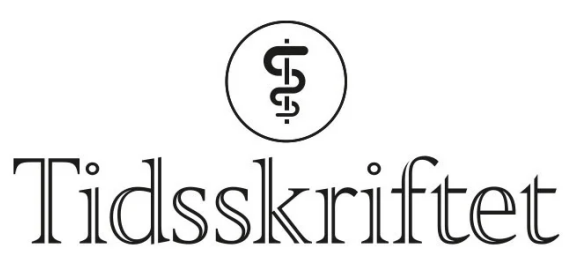

DEN NORSKE LEGEFORENING

\title{
Psykiatrisk forskning og kunnskapsgrunnlag
}

ANMELDELSER

\section{SVEIN FRIIS}

Klinikk psykisk helse og avhengighet

Oslo universitetssykehus, Ullevål

Jørgensen, $\mathrm{P}$

Nordentoft, $\mathrm{M}$

Videbech, P.

Håndbog i psykiatrisk forskning \& evidens

187 s, ill. København: FADL's forlag, 2009. Pris DKK 269

ISBN 978-87-7749-700-1

Forfatterne skriver at boken har som formål «at medvirke til, at psykiatrisk forskning bliver både selvfølgelig og overkommelig i en travl klinisk hverdag og at give let tilgjængeligt overblik over den eksisterende kliniske evidens for behandling av patienter.»

I fire deler omtales følgende:

- Psykiatriens vitenskapelighet og hvordan den har utviklet seg historisk

- Praktiske problemer som man kan forvente å møte når man gir seg i kast med et forskningsprosjekt innenfor psykiatri

- Resymé av den kliniske effektforskning innen de store psykiatriske lidelser og sykdommer

- Gjengivelse av Helsinki-deklarasjonen om retningslinjer for biomedisinsk forskning og Madrid-deklarasjonen om psykiatriens etiske retningslinjer

Målgruppen er alle innenfor det brede voksenpsykiatriske området, enten de ønsker å starte et forskningsprosjekt eller få en introduksjon til klinisk forskning og det eksisterende kunnskapsgrunnlaget for behandling. Videre er målet at kunnskapssøkende pasienter og aktive pårørende skal «finde stikord til den evidensbaserede behandling.» 
Dette er en krevende målsetting. Utfordringen blir ikke mindre av at man har valgt et håndbokformat «for at sikre bogen plads i arbeidstasken, på konferencebordet eller på den lille hylde på kontoret, som kun tillader plads til få bøger.» En av begrensningene ligger nettopp i formatet. Som forfatterne skriver: «Som håndbog er der i valget av sprog og opsætning satset på enkelhed og overskuelighed frem for fuldstændighed og detaljerigdom; disse finder man i andre bøger, som man etterfølgende kan fordybe seg i.» Etter min mening lykkes boken med å gi nøktern og vederheftig informasjon. Men for å dekke så mange områder innenfor liten plass har forfatterne måttet være selektive i hva de tar med. Mange lesere vil nok derfor temmelig raskt føle behov for å gå til mer fullstendige kilder. Boken er derfor først og fremst å betrakte som en appetittvekker.

En liten innvending til slutt:Skriften er så liten at den forutsetter at leseren har godt syn.

Publisert: 6. mai 2010. Tidsskr Nor Legeforen. DOI: 10.4045/tidsskr.10.0078

(C) Tidsskrift for Den norske legeforening 2023. Lastet ned fra tidsskriftet.no 26. april 2023. 